\title{
STUDI EKSPERIMEN REDAMAN GETARAN TRANSLASI DAN ROTASI DENGAN POSISI SUMBER EKSITASI DVA (DYNAMIC VIBRATION ABSORBER)
}

\author{
Abdul Rohman \\ Staf Pengajar Prodi Teknik Mesin, Politeknik Negeri Banyuwangi \\ E-mail : rahman1070@gmail.com
}

Naskah diterima: 13 Juni 2017 ; Naskah disetujui: 26 Juni 2017

\begin{abstract}
ABSTRAK
Getaran merupakan gerakan bolak-balik dari suatu titik kesetimbangan tertentu. Getaran disebut juga osilasi suatu benda di akibatkan oleh gaya. Namun gaya osilasi yang berlebihan akan menimbulkan potensi kerusakan pada sistem. Reduksi getaran dalam frekuensi tunggal dapat dilakukan dengan penambahan DVA. Penelitian ini terkait SDVA untuk mereduksi getaran arah translasi-rotasi terhadap perubahan posisi eksitasi terhadap karakteristik respon getaran translasi-rotasi. Penelitian berbasis eksperimental pada prototype dengan sistem getaran 2 DOF translasi-rotasi dan dengan DVA menjadi 3 DOF. Prototype dimodelkan secara persamaan matematis dan dilakukan simulasi untuk mengetahui respon karakteristik getaran. Dalam eksperimen ini diberikan jarak posisi eksitasi SDVA terhadap dari titik pusat massa. Pengukuran dilakukan dengan pengujian kecepatan motor (gaya eksitasi). Hasil simulasi sebagai referensi hasil eksperimen dengan melihat trend karakteristinya. Hasil penelitian eksperimen nilai percepatan getaran translasi dan rotasi lebih besar daripada nilai hasil simulasi. Nilai eksperimen dengan rasio error prosentase sebesar 26,83\% dan 29,81\% pada redaman arah translasi dan rotasi. Hasil keseluruahn secara ilustrasi trendline grafik redaman eksperimen seirama dengan trendline grafik redaman hasil simulasi. Eksperimen ini dipengaruhi banyak faktor dalam hasil redaman.
\end{abstract}

Kata Kunci: Eksitasi, DVA, DOF, Getaran Translasi dan Rotasi

\section{PENDAHULUAN}

Getaran merupakan osilasi gelombang pada benda dimana jika gaya berlebih pada sistem struktur dapat menimbulkan masalah atau kerusakan. Getaran dapat diredam agar tidak mempengaruhi fungsi kerja dari struktur. Peredaman getaran ini telah banyak dikembangkan sebelumnya dari beberapa penelitian sehingga konsep diciptakan untuk mengurangi getaran tersebut. Konsep Dynamic Vibration Absorber / DVA salah satu yang digunakan untuk meredam respon getaran translasi. DVA merupakan sistem massa tambahan yang dikenakan pada sistem yang bergetar didukung oleh pegas-peredam. Konsep DVA juga digunakan untuk meredam getaran translasi dan rotasi secara bersamaan [1].

Pada penelitian sebelumnya [2], [3] dengan memodifikasi DVA dengan penggunaan Dual DVAIndependent pada sistem utama. Perubahan lengan momen tidak berpengaruh pada getaran arah translasi. Adapun konsep DVA dengan yang dilakukan [4] memodifikasi Dual Dynamic Vibration Absorber /DDVA tersusun secara seri pada sistem utama massa absorber 1 dalam mereduksi getaran massa utama berkurang karena adanya massa absorber 2 yang mengurangi kemampuan getaran.

Salah satu konsep DVA dapat diaplikasikan pada gedung bertingkat [5] terhadap getaran gempa bumi dan getaran juga terjadi pada beam, jembatan serta jalan layang. Dengan banyak konsep tersebut, penelitian ini dilakukan untuk memahami getaran karakteristik untuk merancang sebuah konsep getaran absorber secara dinamis. DVA juga mempunyai istilah lain Tuned Mass Damper/TMD yang secara luas digunakan kontrol getaran secara Passive.

\section{TINJAUAN PUSTAKA}

\section{Dynamic Vibration Absorber (DVA)}

Sebuah sistem dapat mengalami getaran yang berlebihan jika gaya yang bekerja mendekati frekuensi natural dari sistem tersebut. Pada beberapa kasus getaran sebuah sistem dapat dikurangi dengan menambahkan DVA yang terdiri dari massa dengan dihubungkan dengan pegas-peredam. DVA didesain untuk menjauhkan frekuensi natural sistem dari frekuensi gaya yang diberikan pada system utama. Besaran amplitudo getaran pada sistem mengalami peredaman dengan semakin kecil fungsi waktu sebagaimana terlihat pada 
gambar 1. Peredam getaran dinamik atau dynamic vibration absorber (DVA) merupakan adalah satu metode yang banyak dipakai dan cukup mampu untuk meredam getaran yang terjadi pada suatu struktur engineering. Peredam getaran dinamik ditemukan oleh Hermann Frahm (US Patent \#989958, 1911) dan peredam ini banyak digunakan untuk mengatasi permasalahan getaran pada berbagai jenis sistem mekanik yang mengalami gaya atau gangguan eksternal

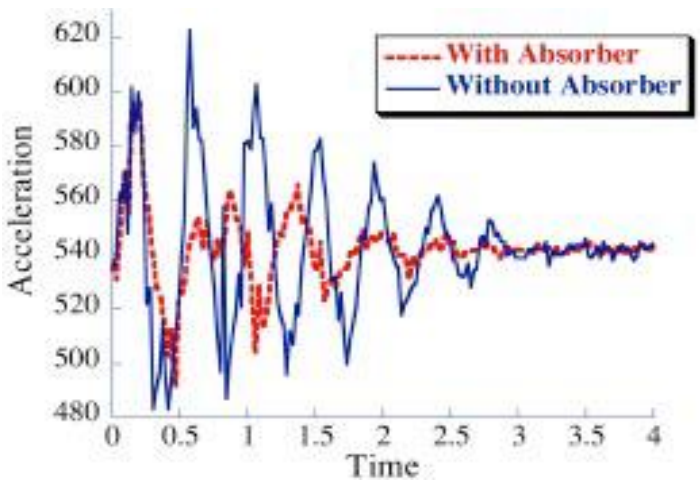

Gambar 1 Perbandingan Hasil Eksperimen Sistem Dengan dan Tanpa Massa Absorber

\section{Dynamic Vibration Absorber (DVA) Tanpa Peredam}

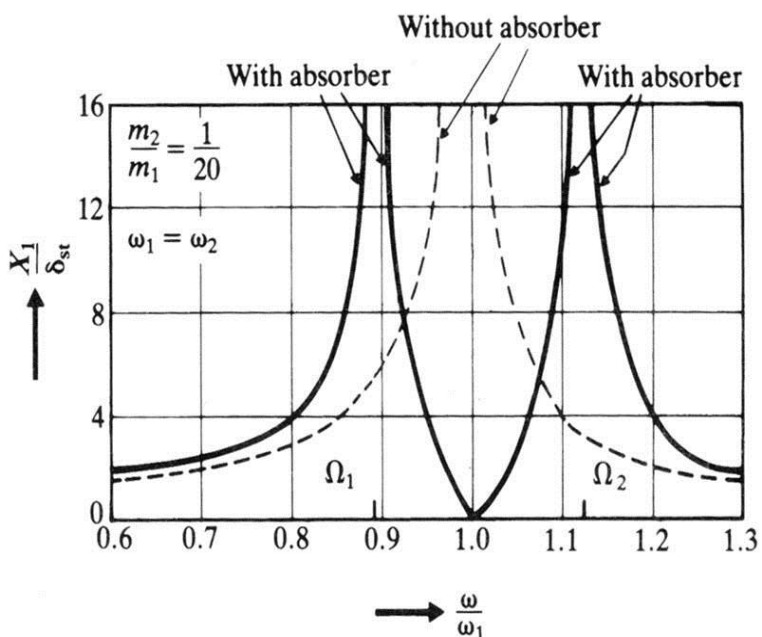

Gambar 2 DVA Tanpa Peredam dan Efek Respon

Pada Gambar 2. memperlihatkan grafik transmisibility perubahan nilai dari amplitudo getaran mesin $\left(\mathrm{X}_{1} / \delta_{\mathrm{st}}\right)$ karena perubahan kecepatan putar mesin $\left(\omega / \omega_{1}\right)$. Dua puncak dari amplitudo sistem utama berkenaan dengan dua frekuensi natural dari sistem komposit

\section{Dynamic Vibration Absorber (DVA) dengan Peredam}

Sistem yang semula hanya memiliki satu buah puncak resonansi, kemudian memiliki dua buah puncak resonansi dengan ditambahkan DVA. Dengan demikian mesin harus melewati resonansi puncak dengan cepat saat mesin dalam kondisi dinyalakan atau dimatikan untuk menghindari amplitudo yang sangat besar. Amplitudo dari mesin ini dapat dikurangi dengan memberikan peredam getaran sebagaimana ditunjukkan pada gambar 2. Pemberian DVA tanpa peredam mengakibatkan berubahnya nilai dan jumlah resonansi puncak dari mesin

\section{METODOLOGI}

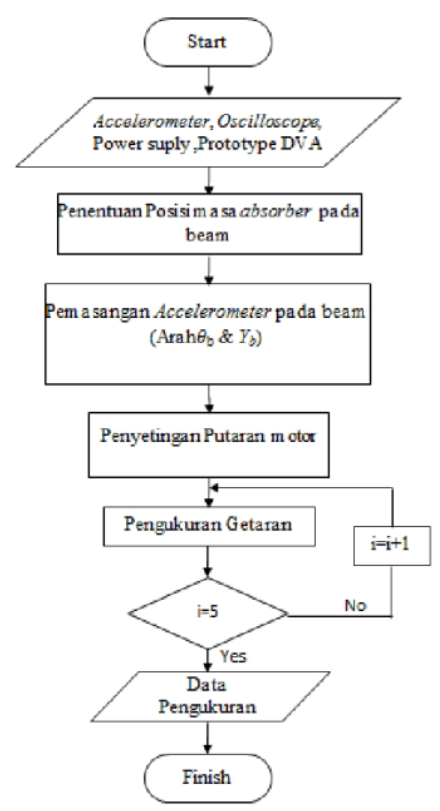

Gambar 3 Diagram Alir Mekanisme Pengukuran Getaran

\section{Alat Penelitian}

Beberapa peralatan pendukung yang digunakan dalam penelitian adalah :
1. Accelerometer
2. Osciloscope
3. Power Supply
4. Inverter
5. Tachometer

\section{Pemodelan Dinamis Sistem DVA}

Pada penelitian ini dapat menentukan pemodelan dinamis sistem dengan persamaan gerak sistem. Dengan menggunakan Program Matlab dapat menentukan blok simulink didapatkan respon getaran. Adapaun sistem 
utama dalam bentuk prototype pada gambar berikut. Nama komponen sebagai berikut : (1) Beam (2) base Metal (3) Kantilever Sistem (4) Motor (5) Massa Unbalance (6) Penggaris (7) Massa Absorber (7) Kotak Penyeimbang

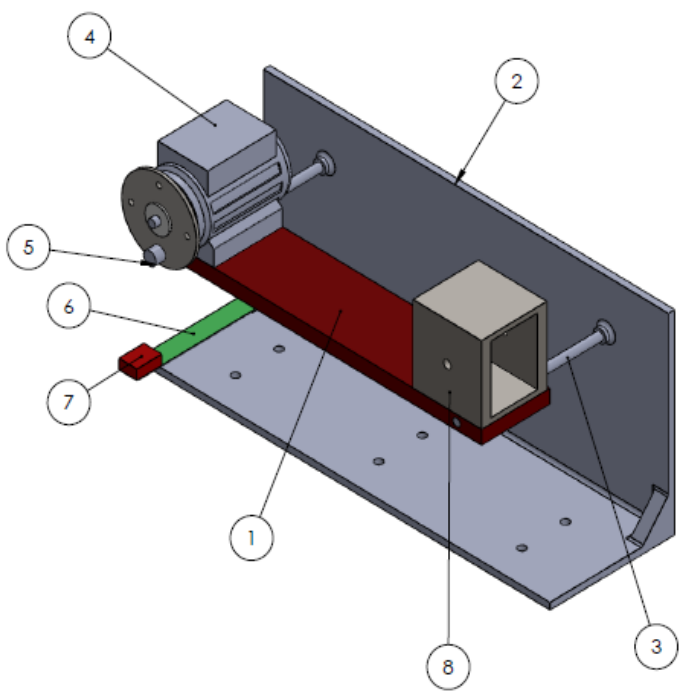

\section{Gambar 4 Mesin Uji (Prototipe) DVA (Dynamic Vibration Absorber)}

Prinsip kerja Mesin Uji ini adalah ilustrasi sistem massa dan pegas yang ingin di redam atau reduksi getarannya. Pada gambar 4 sebuah massa sistem utama pada kedua ujung di topang oleh dua kantilever. Fungsi kantilever adalah pengganti pegas yang diberikan pada sistem. Sistem utama akan diredam getarannya adalah sebuah kesatuan dari beban dinamis sistem seperti massa beam, massa motor, massa balance dan Silinder. Sistem utama dipengaruhi gaya eksitasi dengan beban massa unbalance pada disk plate yang diputar oleh Gaya motor listrik. Pada hal ini posisi pusat massa diasumsikan berada pada titik tengah pada beam sehingga posisi motor berada berseberangan dengan massa balance dengan jarak yang sama. Tujuan penelitian adalah mendapatkan respon yang akan berbeda pada setiap titik peredaman dimana motor sebagai penggerak eksitasi. DVA sebagai massa yang dengan peredaman variable dinamis. Penempatan DVA ini dibagi menjadi beberapa titik yakni pada titik CG (center of gravity), setengah dari panjang terhadap CG dan ujung pada beam. Sebaliknya penempatan DVA pada sisi yang lain. Jarak DVA merupakan dari rasio lengan dengan jarak kantilever terhadap titik CG.

Pemodelan dinamis pada gambar diatas dengan mengacu Hukum Newton dapat menjabarkan suatu persamaan dinamis tersebut. Dalam bentuk persamaan pemodelan terdapat derajat kebebasan pada sistem (Degree of Freedom /DOF) pada sistem tersebut dengan tanpa DVA terlihat 2 DOF namun dengan penambahan DVA maka bertambah jumlah derajat kebebasan menjadi 3 DOF. Dalam penerapan rumus yang diberikan dimana ada 3 persamaan gerak diperoleh dari massa utama, massa absorber dan Inersia. Gerakan yang hasilkan pada sistem ini yaitu Translasi sistem utama $\left(y_{s}\right)$, rotasi sistem $\operatorname{utama}(\theta)$ dan translasi massa absorber $\left(\mathrm{y}_{\mathrm{a}}\right)$. Dari persamaan gerak diatas dapat berbentuk state variable sehingga dapat diperoleh blok Diagram Simulink Matlab.

\section{Parameter Sistem}

Nilai Parameter yang mewakili suatu bagian dari Mesin Uji DVA diukur dengan alat uji dengan perhitungan rumus. Parameter ini sebagai salah satu input dalam simulasi simulink matlab. Parameter dimaksud meliputi : massa, kekakuan, redaman, panjang, dan momen inersia. Adapun nilai parameter yang telah diperoleh dari hasil pengukuran penulis adalah sebagai berikut: ${ }^{(1)} \mathrm{m}_{\mathrm{s}}: 13.88 \mathrm{~kg}^{(2)} \mathrm{k}_{2}: 44802 \mathrm{~N} / \mathrm{m}^{(3)} \mathrm{a}: 0.12,0,145$ dan $0,18 \mathrm{~m}$ (variasi jarak eksitasi) ${ }^{(4)} \mathrm{m}_{\mathrm{m}}: 5 \mathrm{~kg}{ }^{(5)} \mathrm{k}_{1}: 44802$ $\mathrm{N} / \mathrm{m}^{(6)} 1_{1}: 0,23 \mathrm{~m}^{(7)} \mathrm{m}_{\mathrm{ub}}: 5 \mathrm{~kg}{ }^{(8)} \mathrm{c}_{1}: 52.5 \mathrm{~N} . \mathrm{s} / \mathrm{m}^{(9)} 1_{2}: 0,23$ $\mathrm{m}^{(10)} \mathrm{m}_{\mathrm{b}}: 3,88 \mathrm{~kg}{ }^{(11)} \mathrm{c}_{1}: 52.5 \mathrm{~N} . \mathrm{s} / \mathrm{m}^{(12)} \mathrm{r}: 0,045 \mathrm{~m}^{(13)} \mathrm{m}_{\mathrm{d}}$ : $0.14 \mathrm{~kg}{ }^{(14)} \mathrm{I}: 0,2977 \mathrm{~kg} \cdot \mathrm{m}^{2}{ }^{(15)} \mathrm{L}: 0,52 \mathrm{~m}$.

Adapun untuk mengukur konstanta kekakuan didapatkan rumus mekanika bahan dengan memberikan beban pada ujung kantilever pada sistem sehingga kantilever terdefleksi atau lendutan. Pemberian beban ini dilakukan berulang dengan massa beban yang berbeda.

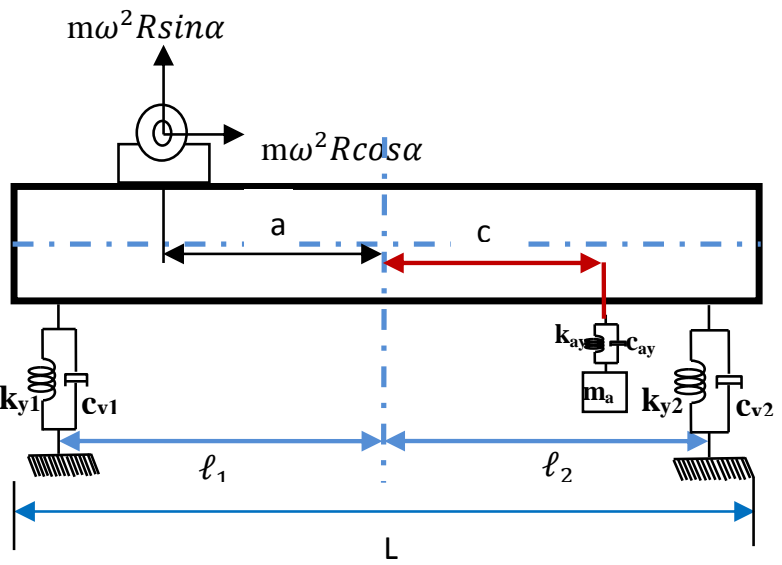

Gambar 5 Model Sistem Dengan Penambahan DVA Dengan Sumber Eksitasi Dari Titik Pusat Massa

Untuk nilai konstanta redaman pengukurannya diperlukan alat uji khusus yakni osciloscope, accelerometer dan power supply. Dalam tahap pengukuran redaman dengan pemasangan accelerometer pada kantilever, dimana diberikan gaya eksitasi atau simpangan awal sebesar $\mathrm{x}_{\mathrm{o}}$ dan dibiarkan bergetar hingga tidak bergetar lagi. Getaran yang timbul dengan pemberian simpangan di rekam pada display osciloscope. Data getaran yang disimpan pada osciloscope masih berupa data voltasi sehingga diperluka konrversi.

Adapun pengukuran redaman kantilever ini menggunakan metode logaritmic decrement dengan persamaan sebagai berikut : 


$$
c=2 \cdot m \cdot \sqrt{(k / m)} \cdot \sqrt{\left(1 /\left(\left(2 \cdot \pi / \ln \left(a_{n} / a_{n+1}\right)\right)^{2}+1\right)\right.}
$$

Di mana $a_{n}$ adalah besar amplitudo getaran ke-n, $\mathrm{a}_{\mathrm{n}+1}$ besar amplitudo getaran ke-( $\left.\mathrm{n}+1\right)$. Nilai redaman dari kantilever absorber dapat diperoleh dengan menggunakan persamaan logaritmic degreement dengan langkah yang sama perbedaan penempatan accelerometer pada kantilever absorber.

\section{Prosedur Pengujian}

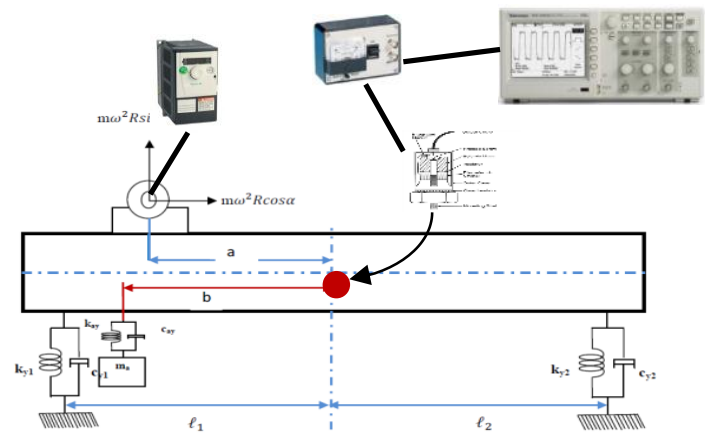

Gambar 6 Skema Rangkaian Pemasangan Accelerometer Mengukur Getaran Arah Translasi (Ys)

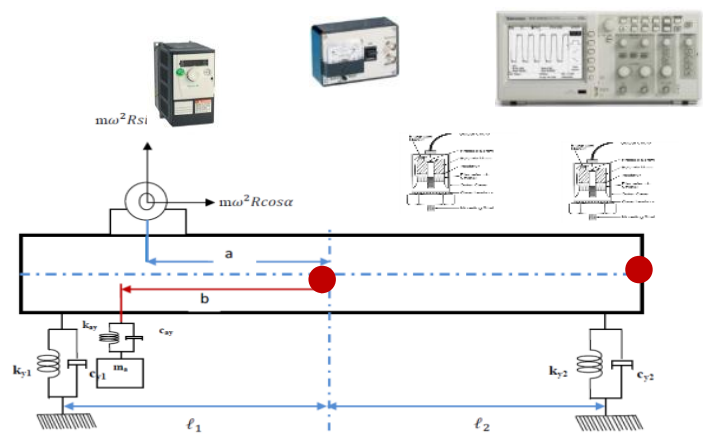

Gambar 7. Skema Rangkaian Pemasangan Accelerometer Mengukur Getaran Arah Rotasi $(\theta)$

\section{HASIL DAN PEMBAHASAN}

Hasil running simulink dalam persamaan state variable pada sistem blok diagram akan menghasilkan respon. Simulasi ini dirancang untuk mengetahui Root Mean Square (RMS) respon getaran dari sistem dimana sistem ini terdiri dari Non-DVA dan dengan DVA. Kegiatan pengukuran eksperimen akan memberikan validasi hasil simulasi.

Proses RMS ini juga dengan melakukan nilai sumber eksitasi dari titik pusat massa sistem. Besar frekuensi diberikan pada kisar $0 \mathrm{~s} / \mathrm{d} 30 \mathrm{Hertz}$ disesuaikan dengan kemampuan kerja frekuensi maksimum motor listrik. Lengan momen DVA (c) pada di titik pusat massa dengan asumsi titik nol sampai $0,26 \mathrm{~m}$ ujung dari sisi beam dan sebaliknya juga variasi lengan momen (b) dari titik nol pusat massa sampai $0,26 \mathrm{~m}$ ujung dari sisi beam. Untuk massa dan kekakuan massa dan kekakuan absorber berdasarkan rasio massa dan kekakuan menggunakan rasio $1 / 10$ dari massa dan kekakuan sistem.

Dalam grafik karakteristik yang dihasilkan dilakukan normalisasi. Dimana rasio lengan (rl), merupakan hasil normalisasi antara lengan (b) terhadap jarak pusat massa beam terhadap kantilever $\left(l_{1}\right)$. Begitu juga dengan rasio frekuensi translasi $\left(\mathrm{r}_{\mathrm{f}}\right)$ dan roasti $\left(\mathrm{r}_{\mathrm{fr}}\right)$ adalah normaliasi frekuensi natural arah translasi dan arah rotasi. Pengujian kecepatan motor dilakukan Sebagai nilai input yang diberikan sebagai frekuensi eksitasi oleh inventer. Adapun nilai besaran inventer di atur 10 sd 35 . Frekuensi yang sebenarnya dapat dilakukan dengan tachometer inframerah.

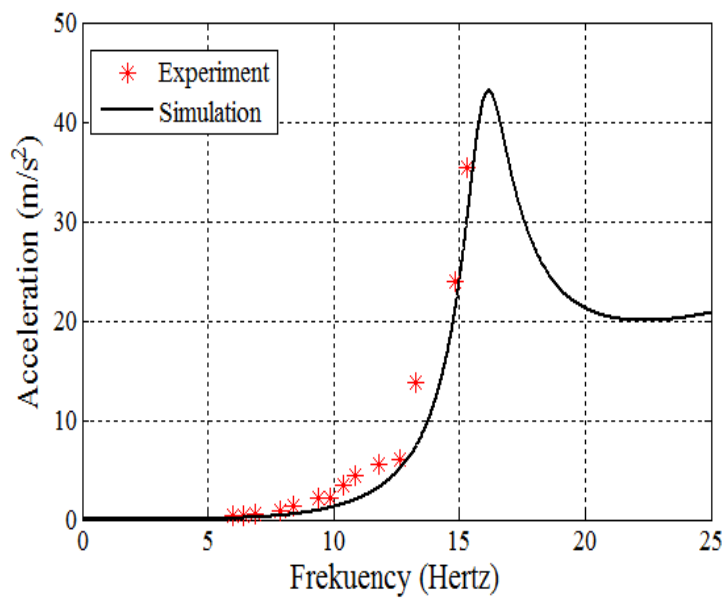

Gambar 8 Grafik Validasi Reduksi Getaran Arah Translasi tanpa DVA

Pada hasil simulasi rms percepatan translasi pada puncak terendah pada titik $0,119 \mathrm{~m} / \mathrm{s}^{2}$ Sedangkan hasil eksperimen pada puncak $0,128 \mathrm{~m} / \mathrm{s}^{2}$ dengan nilai frekuensi 15,31 Hz. Pada hasil simulasi rms percepatan translasi pada puncak tertinggi pada titik $30,21 \mathrm{~m} / \mathrm{s}^{2}$ Sedangkan hasil eksperimen pada puncak $35,462 \mathrm{~m} / \mathrm{s}^{2}$ dengan frekuensi $15,31 \mathrm{~Hz}$. Trendline grafik getaran translasi yang terjadi menunjukkan dengan frekuensi yang dimulai rendah hingga tinggi rms percepatan pada hasil eksperimen lebih besar daripada rms percepatan simulasi. Dimana rata-rata error $(\%)$ sebesar 20,06 \%. Dikarenakan gaya yang bekerja pada kondisi berlebih dikarenakan besaran operasinya mendekati frekuensi tunggal hal ini karena kontruksi sistem utama yang mengalami getaran. 


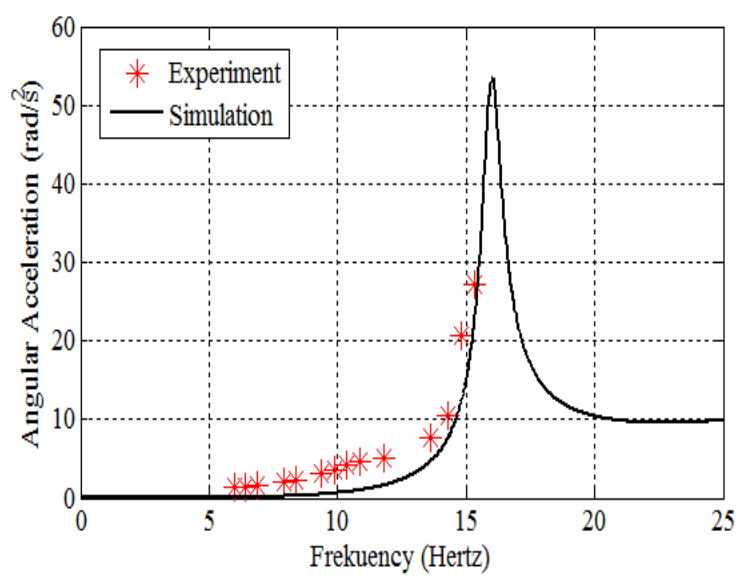

Gambar 9 Grafik Validasi Reduksi Getaran Arah Rotasi tanpa DVA

Hasil validasi eksperimen dan simulasi penelitian ini dalam rata-rata error pengukuran sebesar 28,36 \%. Pada hasil simulasi rms percepatan rotasi pada puncak terendah pada titik $0,068 \mathrm{~m} / \mathrm{s}^{2}$ Sedangkan hasil eksperimen pada puncak $0,159 \mathrm{~m} / \mathrm{s}^{2}$ dengan nilai frekuensi 5,99 Hz. Pada hasil simulasi rms percepatan pada puncak tertinggi pada titik $23,36 \mathrm{~m} / \mathrm{s}^{2}$ Sedangkan hasil eksperimen pada puncak $27,28 \mathrm{~m} / \mathrm{s}^{2}$ dengan frekuensi $15,31 \mathrm{~Hz}$.

Hasil eksperimen yang lebih besar disebabkan redaman kantilever dipengaruhi oleh jenis material dengan getaran yang terjadi yang terus menerus sehingga akan mengurangi kemampuan meredam material tersebut sehingga reduksi terhadap getaran DVA semakin menurun. Dengan menurunnya redaman tersebut maka resonansi mempunyai nilai yang semakin meningkat seiring waktu getaran berlangsung.

Dengan adanya penambahan massa absorber maka terjadi 2 puncak resonansi dengan besaran frekuensi natural masing-masing. Dengan adanya dua puncak resonansi getaran maka terdapat nilai maksimum dengan frekuensi yang sama pada setiap puncaknya. Hasil getaran eksperimen yang besar daripada hasil simulasi disebabkan oleh pegas absorber yang memiliki daya yang terbatas dalam melakukan peredaman.

Material pegas atau kantilever akan melemah jika dikenai beban terus menerus dikarenakan oleh sifat fisik material tersebut. Begitu juga mengenai bentuk pegas absorber yang pipih mengakibatkan kemungkinan retak lebih besar sehingga mempengaruhi performance saat menahan getaran. Dengan adanya perbedaan prosentase error diatas maka terlihat dari trendline grafik diatas dapat diartikan bahwa adanya kesamaan hasil simulasi dan eksperimen pada penelitian ini.

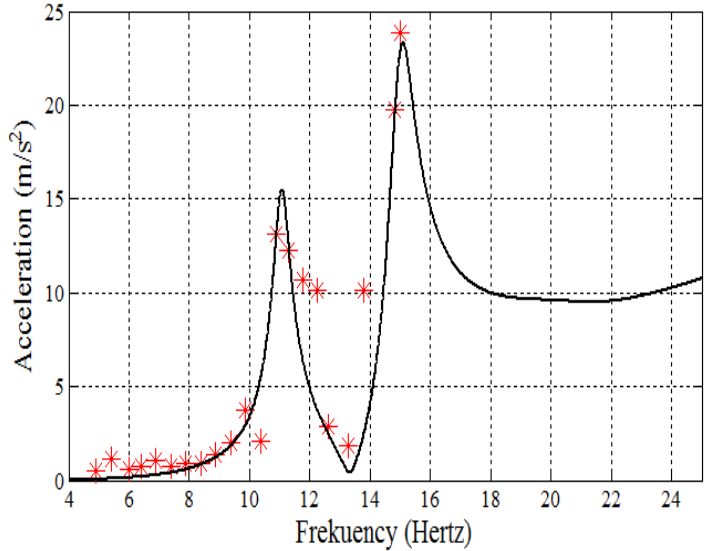

Gambar 10 Grafik Validasi Reduksi Getaran Arah Translasi Dengan DVA

Dengan adanya tiga puncak resonansi getaran maka terdapat nilai maksimum dengan frekuensi yang masing-masing sama. Nilai resonansi pertama yang pada gambar tersebut rms percepatan pada hasil eksperimen $13,47 \mathrm{~m} / \mathrm{s}^{2}$ pada frekuensi 10,87 Hertz.. Pada gambar tersebut resonansi maksimum yang ke-2 dengan rms percepatan pada hasil eksperimen $23,86 \mathrm{~m} / \mathrm{s}^{2}$ pada frekuensi 14,81 Hertz. Pada hasil rms percepatan resonansi maksimum hasil simulasi $22,73 \mathrm{~m} / \mathrm{s}^{2}$ dengan frekuensi yang sama. Dengan perbedaan nilai respon getaran yang terjadi cukup besar dengan rata-rata error (\%) sebesar $26,83 \%$

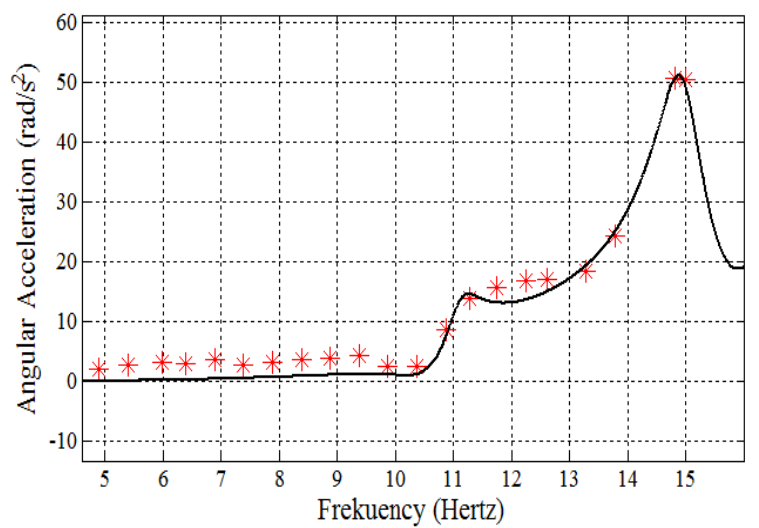

Gambar 11 Grafik Validasi Reduksi Getaran arah Rotasi Dengan DVA

Dengan perbedaan nilai respon getaran yang terjadi yang cukup besar dimana dengan prosentase ratarata sebesar $29,81 \%$ untuk puncak pertama dengan resonansi eksperimen $15,5 \mathrm{~m} / \mathrm{s}^{2}$ pada frekuensi $11,28 \mathrm{~Hz}$. Pada gambar tersebut resonansi maksimum yang ke-2 dengan rms percepatan pada hasil eksperimen 50,86 $\mathrm{m} / \mathrm{s}^{2}$ pada frekuensi 14,81 Hertz. Pada hasil rms percepatan resonansi maksimum baik hasil simulasi dan eksperimen sebesar $50,58 \mathrm{~m} / \mathrm{s}^{2}$ dengan frekuensi yang sama. 
Untuk puncak kedua hal ini terjadi karena adanya gaya eksitasi yang diberikan oleh motor pada saat start dimulai sebelum mencapai beban putaran konstan, sehingga nilai rms yang dihasilkan sedikit lebih tinggi di bandingkan dengan simulasi.

Dengan besarnya prosentase error yang terjadi diakibatkan dengan adanya perpindahan atau konduktifitas getaran sebagian besar dari sistem ke body base hingga ke meja sebagai dudukan utama. Hal ini terjadi dengan adanya penambahan frekuensi yang diberikan sehingga menambah beban gaya eksitasi pada getaran yang ditimbulkan sangat tinggi. Dengan demikian getaran akan mempengaruhi getaran pada meja ekperimen. Dengan adanya perbedaan rata-rata keseluruhan prosentase error yang besar maka terlihat dari trendline grafik diatas dapat diartikan bahwa adanya kesamaan hasil penelitian secara simulasi dan eksperimen

\section{KESIMPULAN}

Berdasarkan hasil eksperimen yang dihasilkan pada redaman arah translasi dan rotasi mampu mereduksi getaran di rasio frekuensi rata-rata error $26,83 \%$ dan $29,81 \%$. Pengurangan getaran translasi maksimum untuk rentang frekuensi $5,99 \mathrm{~Hz}$ s.d $15,31 \mathrm{~Hz}$ untuk arah translasi dan 5,99 $\mathrm{Hz}$ s.d $15,31 \mathrm{~Hz}$ untuk arah rotasi Besarnya prosentase error terjadi akibat perpindahan getaran sebagian bear dari sistem ke body base ke meja laboratorium. Dengan adanya perbedaan rata-rata keseluruhan prosentase error sebesar 29,81\% diatas maka terlihat dari trend grafik diatas dapat diartikan bahwa adanya kesamaan hasil penelitian secara simulasi dan eksperimen.

\section{SARAN}

Pemilihan konstruksi dan parameter pegas sangat menentukan besar dan kecilnya respon getaran. Hal ini memungkinkan sistem DVA lebih banyak mereduksi getaran pada arah translasi dan rotasi, bentuk pegas sebagai penopang sistem digantikan dengan spring / pegas ulir yang mempunyai kelenturan dalam arah gaya rotasi. Namun demikian nilai kekakuan perlu dipertimbangkan agar reduksi getaran sesuai dengan desain yang diinginkan

\section{DAFTAR PUSTAKA}

[1] Susastro. 2015. Pengaruh Perubahan Posisi Massa SDVA Dari Titik Berat Massa Utama Terhadap Karakteristik Getaran Translasi-Rotasi Sistem Utama 2 DOF, ST.MT. Tesis, Institut Teknologi Sepuluh Nopember, Surabaya.
[2] Kusumadewayanti, E. 2015. Studi Pengaruh Penambahan Dual Dynamic Vibration Absorber (DVA) -Independet terhadap Respon Getaran Translasi dan Rotasi Pada Sistem Utama 2 DOF, ST.MT. Tesis Institut Teknologi Sepuluh Nopember, Surabaya.

[3] Krenk, Steen. 2013. "Tuned Mass Absorber On A Fleksible Structure”. Science Direct. 1577-1595.

[4] Lostari. A. 2015. Studi Perbandingan Pengaruh Penambahan SDVA dan DDVA Tersusun Seri Terhadap Respon Getaran Translasi Sistem Utama. ST.MT. Tesis Institut Teknologi Sepuluh Nopember, Surabaya.

[5] Yoshida, Kazuo. 1996. “Active Vibration Control For Builder Subjected To Horizontal And Vertical Large Seismic Excitation”. IEEE Procedings of the 35 th. Coference on decision abd Control.78033590-2.

[6] Kefu \& Liu. 2005. "The Damped Dynamic Vibration Absorber : Revisited and Result", Journal of Sound and Vibration 284 (2005) 11811189 